\title{
PEMANFAATAN DAUN PALLIASA (Kleinhovia hospita L) SEBAGAI BAHAN ALTERNATIF DALAM MEMPERTAHANKAN KESEGARAN IKAN KEMBUNG (Rastrelliger sp)
}

\section{(The Utilization of Palliasa Leaves (Kleinhovia hospita L) as an Alternative to Sustain Quality of Mackerel (Rastrelliger sp))}

\author{
Jalil Genisa $^{1)}$, A Nur Faidah Rahman ${ }^{1)}$, dan Kurniati Tajuddin ${ }^{2)}$ \\ 1*) Program Studi Ilmu dan Teknologi Pangan, Fakultas Pertanian, Universitas Hasanuddin, Makassar, Indonesia \\ 2) Mahasiswa Program Studi Ilmu dan Teknologi Pangan, Fakultas Pertanian, Universitas Hasanuddin, Makassar, \\ Indonesia \\ *) email Penulis Korespondensi: jalilgenisa12@gmail.com
}

\begin{abstract}
ABSTRAK
Ikan kembung merupakan salah satu bahan pangan yang memiliki sifat yang mudah mengalami pembusukan atau kerusakan. Pembusukan ini dapat diakibatkan oleh adanya aktivitas mikroorganisme seperti Salmonella typhi, Staphlococcus aureus dan Streptococcus mutanas. Daun palliasa (Kleinhovia hospita L) adalah salah satu tanaman herbal khas Sulawesi Selatan yang berkhasiat dan mampu berperan sebagai antibakteri dan antijamur. Sementara itu, daun palliasa mengandung beberapa senyawa antibakteri yaitu alkaloid, flavonoid, dan terpenoid. Tujuan dari penelitian ini adalah untuk mengetahui pengaruh penggunaan ekstrak daun palliasa terhadap kesegaran ikan kembung selama penyimpanan. Tahapan penelitian yang dilakukan yaitu persiapan bahan baku, perendaman, penyimpanan dan pengujian. Pengujian yang dilakukan meliputi uji total mikroba, nilai $\mathrm{pH}$, kadar air dan pengujian organoleptik. Perlakuan yang digunakan adalah perendaman ikan segar dalam ekstrak daun palliasa dengan konsentrasi 2\%, 3\% dan 4\% selama 15 menit. Hasil penelitian menunjukkan bahwa perendaman dalam ekstrak daun palliasa dapat menghambat pertumbuhan mikroba. Berdasarkan hasil penelitian perlakuan konsentrasi daun palliasa yaitu 2\%. 3\%, dan 4\% terhadap kesegaran ikan kembung selama penyimpanan suhu ruang, dapat disimpulkan bahwa keefektifan daun palliasa dalam mempertahankan kesegaran ikan kembung yaitu dengan konsentrasi daun palliasa 3\% hingga penyimpanan 8 jam lebih lama dibandingkan dengan kontrol (tanpa perendaman ekstrak daun palliasa) dengan nilai rata-rata 7 (diterima/baik). Di samping itu, perlakuan perendaman ekstrak daun palliasa dapat meningkatkan nilai organoleptik ikan. Daun palliasa mampu menghambat pertumbuhan mikroorganisme.
\end{abstract}

Kata Kunci : ikan kembung, daun palliasa, penyimpanan ikan

\section{ABSTRACT}

Mackerel is one of the ingredients that has perishable food. This decay can be caused by the activity of microorganisms such as Salmonella typhi, Staphlococcus aureus and Streptococcus mutanas. Palliasa leaf (Kleinhovia hospita L) is one of herbal plant from south Sulawesi is efficacious and able to act as antibacterial and antifungal. Meanwhile, palliasa leaf contains several antibacterial compounds namely alkaloids, flavonoids, and terpenoids. The purpose of this research was to know the effect of using palliasa leaf extract to freshness of mackerel during storage. Step of research were preparation of raw materials, soaking, storage and testing. Testing conducted include total microbial tests, $\mathrm{pH}$ values, moisture content and organoleptic testing.The treatment used was fresh fish immersion in palliasa leaf extract with concentration of 2\%, 3\% and 4\% for 15 minutes. The results showed that soaking in palliasa leaf extract can inhibit microbial growth. Based on result of research of palliasa leaf concentration that is $2 \% .3 \%$, and $4 \%$ to freshness of 
mackerel during storage of room temperature can be concluded that the effectiveness of palliasa leaves in maintaining freshness of mackerel ie with palliasa leaf concentration 3\% up to 8 hours longer storage than control (without soaking palliasa leaf extract) with average score of 7 (accepted). In addition, the soaking treatment of palliasa leaf extract can increase the organoleptic value of the fish. Palliasa leaf able to inhibit the growth of microorganisms.

Keywords : Mackerel, Palliasa leaf, fish storage

\section{PENDAhuluan}

Daun Palliasa (Kleinhovia hospita L)merupakan salah satu tanaman khas Sulawesi Selatan yang berkhasiat dan dapat berperan sebagai antibakteri dan antijamur. Memiliki peran sebagai antimikroba, daun palliasa (Kleinhovia hospita L) mampu memberikan efektivitas daya hambat yang baik terhadap pertumbuhan mikroorganisme pada bahan pangan khususnya pada ikan. Pertumbuhan bakteri yang terhambat akan mencegah pembusukan pada ikan segar (Bord Iascaigh hara, 1999). Beberapa senyawa antibakteri yang terkandung pada daun palliasa (Kleinhovia hospita L) yaitu alkaloid, flavonoid, terpenoid, tanin dan saponin (Wiwi, 2005). Penggunaan anti mikroba yang tepat dapat memperpanjang umur simpan sekaligus menjamin keamanan produk pangan. Adapun jenis mikroba yang dapat dihambat seperti Salmonella typhi, Staphylococcus aureus dan Streptococcus mutans. Ikan adalah salah satu hasil perairan sekaligus sumber pangan hewani yang banyak dikonsumsi oleh masyarakat. Sebagai sumber pangan hewani dan mengandung berbagai nilai gizi yang tinggi, namun pada umumnya ikan memiliki sifat yang mudah mengalami pembusukan/kerusakan (perishable food). Hal tersebut dikarenakan adanya faktorfaktor intrinsik dan ekstrinsik yang mempengaruhi. Adapun faktor intrinsik pemicu pembusukan adalah tingginya kadar air yang berkisar $70 \%$ sehingga mempercepat pertumbuhan bakteri, rendahnya kadar kolagen, tingginya kadar lemak tak jenuh dan komposisi nitrogen terurai dalam tubuh ikan. Sedangkan faktor ekstrinsik yang memicu pembusukan ikan adalah lokasi penanganan, musim dan metode penangkapan (Japan International Cooperation Agency, 2008).Hal seperti inilah yang harus memerlukan penanganan yang cukup baik agar mutu kesegarannya dapat dipertahankan. Berdasarkan hasil data statistik Republik Indonesia (2013) tercantum bahwa salah satu ikan menempati posisi tertinggi dalam volume produksi perikanan tangkap adalah ikan kembung (Rastrelliger $s p$ ). Oleh karena itu, dengan tingginya volume produksi perikanan tangkap terhadap ikan kembung (Rastrelliger sp), mengharuskan nelayan maupun pedagang untuk tetap menjaga kesegaran ikan. Ikan kembung (Rastrelliger sp) merupakan salah satu sumberdaya perikanan pelagis, dan mempunyai nilai ekonomis penting. Tidak hanya memiliki nilai ekonomis, namun ikan layang memiliki tekstur daging yang kompak, dan cita rasa yang banyak 2 digemari oleh masyarakat sehingga dapat menjadi salah satu sumber gizi untuk pemenuhan protein hewani. Akan tetapi, ikan kembung(Rastrelliger $s p$ ) memiliki sifat yang sama dengan komoditas perikanan lainnya, yaitu mudah mengalami kerusakan oleh enzim maupun mikrobiologi. Oleh sebab itu diperlukan proses penanganan yang tepat dan benar agar masa simpannya dapat diperpanjang. Berbagai macam proses penanganan ikan yang telah dilakukan oleh masyarakat. Namun tidak sedikit dari masyarakat yang menggunakan bahan-bahan yang dapat membahayakan kesehatan seperti penggunaan formalin. Penanganan ikan meerupakan hal yang sangat penting untuk diperhatikan. Hal tersebut sangat berkaitan dengan menentukan baik buruknya ikan tersebut. baik buruknya penanganan ikan segar akan 
mempengaruhi mutu ikan sebagai bahan makanan atau sebagai bahan mentah untuk proses pengolahan lebih lanjut. Penanganan yang salah, serta kandungan air yang cukup tinggi menyebabkan ikan tersebut mudah mengalami proses pembusukan atau kerusakan.. dengan kondisi demikian, ikan tidak dapat dimanfaatkan lagi sebagai kebutuhan asupan gizi bagi manusia. Oleh karena itu, untuk mencegah proses pembusukan perlu dikembangkan berbagai cara pengawetan dan pengolahan yang tepat dan cerat agar sebagian ikan yang diproduksi dapat dimanfaatkan. Berdasarkan penjelasan di atas, maka dapat dilakukan penelitian dengan menguji mutu ikan kembung dari pengaruh ekstrak daun palliasa (Kleinhovia hospita $L$ ) sebagai bahan alternatif dalam menjaga kesegaran, memperpanjang umur simpan sehingga menjaga mutu ikan dari penyalahgunaan bahan zat aditif seperti formalin.

\section{METODOLOGI PENELITIAN}

\subsection{Alat}

Alat yang digunakan dalam penelitian ini adalah alat yang digunakan adalah cool box, talenan, pisau, loyang. Alat untuk analisis TPC (Total Plate Count), yaitu erlenmeyer, magnetic stirrer, hot plate, autoclave, timbangan analitik, oven, desikator, tabung reaksi dan rak, cawan petri, inkubator, mikropipet dan alat yang digunakan untuk analisis kimia adalah $\mathrm{pH}$ meter.

\subsection{Bahan}

Bahan yang digunakan dalam penelitian ini adalah daun palliasa,ikan kembung, NaCl, PCA (Plate Count Agar), tissue, aquadest, kapas, label dan aluminium foil.

\subsection{Prosedur Penelitian}

Prosedur penelitian ini terdiri dari 2 tahapan yaitu tahap penelitian pendahuluan, kemudian dilanjutkan penelitian utama sebagai tahap kedua sebagai berikut.

\subsubsection{Penelitian Pendahuluan}

Penelitian pendahuluan dilakukan secara eksperimental. Penelitian ini bertujuan untuk memperoleh formulasi daun palliasa yang digunakan sebagai bahan alternatif dalam mempertahanan kesegaran ikan. Penelitian pendahuluan dilakukan dengan membuat ekstrak daun palliasa. Terdapat 3 macam jenis daun palliasa yang digunakan yaitu daun palliasa muda, tua dan kering. Penggunaan formulasi yang digunakan untuk masing-masing daun yaitu (1 gram, 2 gram, 3 gram, 4 gram, 5 gram, 6 gram, 7 gram, 8 gram, 9 gram, dan 10 gram). Berdasarkan formulasi tersebut, masing masing daun diaplikasikan ke ikan dan diuji total mikroba setelah penyimpanan 4 jam. Berdasarkan hasil pengujian.

Perlakuan terbaik yang diperoleh pada formulasi 9 gram+ $300 \mathrm{ml}$ air pada daun palliasa muda, dan dijadikan acuan pada penelitian utama untuk dianalisa kadar air, $\mathrm{pH}$, total mikroba dan organoleptik. Formulasi terbaik yang dhasilkan yaitu 9 gram (3\%) juga telah dihasilkan pada penelitian sebelumnya yaitu pada penelitian Raflin Djafar pada tahun 2014 dengan menggunakan ekstrak belimbing wuluh pada ikan layang.

\subsubsection{Penelitian Utama}

Penelitian utama dilakukan dengan membuat ekstrak daun palliasa muda sebanyak 9 gram atau jika di persenkan sebanyak 3\% dalam $300 \mathrm{ml}$ air yang merupakan hasil dari perlakuan pada penelitian pendahuluan. Hasil terbaik yang diperoleh pada formulasi daun palliasa muda, kemudian dibuat formulasi baru dengan cara mengambil angka dibawah dan diatas 9 gram, yaitu 6 gram atau 2\% dan 12 gram atau $4 \%$ dengan penambahan air yang sama (300 ml semua perlakuan). Selanjutnya dilakukan pengujian berupa kadar air, pH, uji total mikroba dan uji organoleptik. Adapun perlakuan penelitian, dapat dihasilkan dengan menggunakan rumus yaitu :

A1 : $2 \%(\times 100 \%)$

A2 : $3 \%(\times 100 \%)$ 
A3 : 4\% $(\times 100 \%)$

\subsubsection{Prosedur Kerja Pembuatan Ekstrak Daun Palliasa}

Perlakuan dalam penelitian ini ada 3 yaitu : $\mathrm{A} 1=2 \%, \mathrm{~A} 2=3 \%$, dan $\mathrm{A} 3=4 \%$. Konsentrasi daun palliasa dalam penelitian adalah banyaknya daun palliasa yang dilarutkan dalam $300 \mathrm{ml}$ air.

Banyaknya daun palliasa yang diperlukan dalam masing-masing perlakuan diperoleh dari :

a. $2 \%=6$ gram daun palliasa muda

b. $3 \%=9$ gram daun palliasa muda

c. $4 \%=12$ gram daun palliasa muda

Perhitungan konsentrasi daun palliasa : Rumus yang digunakan : $\frac{\text { berat bahan }}{300 \text { gr air }} \times 100 \%$

Konsentrasi 2\%, 3\%, dan 4\% dilarutkan dalam $300 \mathrm{ml}$ air dapat diperoleh berdasarkan rumus diatas.

Pembuatan ekstrak daun palliasa dapat dilakukan dengan menggunakan 3 perlakuan yaitu 2\%,3\% dan 4\%. Ekstrak daun palliasa dibuat dengan cara: Pembilasan. Daun yang akan digunakan, terlebih dahulu dibersihkan dari kotoran yang melekat pada daun. Dicuci dengan air bersih, Pemotongan. Daun yang telah dibilas dan dibersihkan, kemudian dipotong kecil-kecil kurang lebih $1 \mathrm{~cm}$., Penambahan air dan penghancuran untuk mendapatkan ekstrak, daun ditambahkan air masing-masing $300 \mathrm{ml}$ dan kemudian dihancurkan dengan menggunakan blender. Penyaringan. Larutan yang dihasilkan, kemudian disaring dengan menggunakan kain saring untuk dipisahkan dari ampasnya. Rendemen yang dihasilkan setelah penyaringan adalah sebanyak $289 \mathrm{ml}$.

\subsubsection{Perendaman dan Penyimpanan}

Masing-masing perlakuan terdiri dari dua ikan kembung berukuran panjang \pm panjang rata-rata $18 \mathrm{~cm}$. Perendaman dengan menggunakan ekstrak daun palliasa dilakukan pada suhu ruang selama 15 menit. Ikan yang telah direndam, dipindahkan kewadah bersih Styrofoam dengan ukuran panjang $15,5 \mathrm{~cm}$ dan lebar $9 \mathrm{~cm}$ yang telah diberi label untuk disimpan disuhu ruang. Pengamatan dilakukan setiap 4 jam sekali sampai ikan mengalami kebusukan.

\section{HASIL DAN PEMBAHASAN}

Berdasarkan penelitian pendahuluan diketahui bahwa daun palliasa muda memiliki nilai total mikroba yang lebih sedikit yaitu dibandingkan dengan daun palliasa tua maupun kering sehingga dapat dilanjutkan pada penelitian utama dengan membandingkan kembali formulasi terbaik dari penelitian pendahuluan dengan formulasi baru. ekstrak daun palliasa muda dengan 3 formulasi yaitu $2 \%$, 3\% dan $4 \%$ dalam $300 \mathrm{ml}$ air. Ketiga formulasi tersebut, digunakan dan dilakukan perendaman terhadap ikan kembung selama 15 menit. Masing-masing perlakuan terdiri dari 2 ikan kembung berukuran panjang rata-rata $18 \mathrm{~cm}$ dengan berat 150 gr. Ikan kembung yang telah direndam diangkat dari rendaman tersebut untuk dipindahkan ke wadah yang bersih dan simpan pada suhu ruang selama 4-16 jam. pengujian dilakukan setelah ikan disimpan perempat jamnya hingga 16 jam yang meliputi uji jumlah total mikroba, $\mathrm{pH}$ daging ikan, kadar air dan organoleptik berupa kenampakan (mata, insang, lendir), tekstur dan aroma.

\subsection{Kadar Air}

Kadar air berperan penting dalam proses kemunduran mutu suatu bahan pangan seperti pada ikan. Dengan kandungan air cukup tinggi tubuh ikan (78\%) merupakan media yang cocok untuk kehidupan bakteri pembusuk atau mikroorganisme yang lain. Hal tersebut sangat mudah mempengaruhi ikan dan cepat mengalami proses pembusukan atau penurunan mutu. Hasil pengujian kadar air daging ikan kembung dengan perlakuan ekstrak daun palliasa selama penyimpanan 16 jam pada suhu ruang dapat dilihat pada Gambar 1. Hasil penelitian menunjukkan bahwa kadar air ikan berkisar antara 73,48$82,73 \%$. 
Hasil analisis sidik ragam menunjukkan tidak terdapat pengaruh kadar air padaperlakuan perendaman dalam ekstrak daun palliasa. Hal ini kemungkinan karena ikan pada seluruh perlakuan direndam selama 15 menit. Penurunan kadar air dapat dipengaruhi oleh konsentrasi daun palliasa yang rendah. Rerata kadar air yang rendah diperoleh pada perlakuan ekstrak daun palliasa 3\% sedangkan kadar air tertinggi diperoleh dari ikan kembung tanpa perlakuan atau tanpa penambahan ekstrak daun palliasa (kontrol). Perlakuan pada setiap perlakuan mengalami penurunan selama penyimpanan pada jam ke 0 sampai jam ke-8. Penurunan kadar air diduga karena peningkatan kadar fenol sewaktu perendaman yang terdapat pada daun palliasa pada jam ke 0 hingga jam ke-8. Fenol merupakan salah satu senyawa yang memiliki sifat misable yakni senyawa yang dapat bercampur. Fenol merupakan senyawa solute (zat pelarut) yang akan terlarut dalam air. Kenaikan kadar fenol dipengaruhi oleh turunnya kadar air. Penurunan kadar air menyebabkan konsentrasi fenol menjadi pekat. Menurut Environmental Protection Agency (2002), fenol memiliki sifat yang mudah menguap namun penguapan fenol lebih lambat dari air. Pada jam ke-12 hingga jam ke-16 kadar air meningkat. Peningkatan ini disebabkan oleh kandungan fenol yang menurun. Peningkatan kadar air pada jam ke-12 dan jam ke-16 juga diduga karena proses denaturasi protein daging ikan yang dapat membebaskan air selama penyimpanan disuhu ruang, meningkatnya kadar air dalam daging ikan dapat menyebabkan berkurangnya kekenyalan. Semakin lama penyimpanan maka kandungan airnya semakin bertambah. Tingginya kadar air menjadi penyebab pertumbuhan mikroorganisme pembusuk. Buckle (1987) mengatakan bahwa, pengaruh kadar air sangat penting dalam menentukan

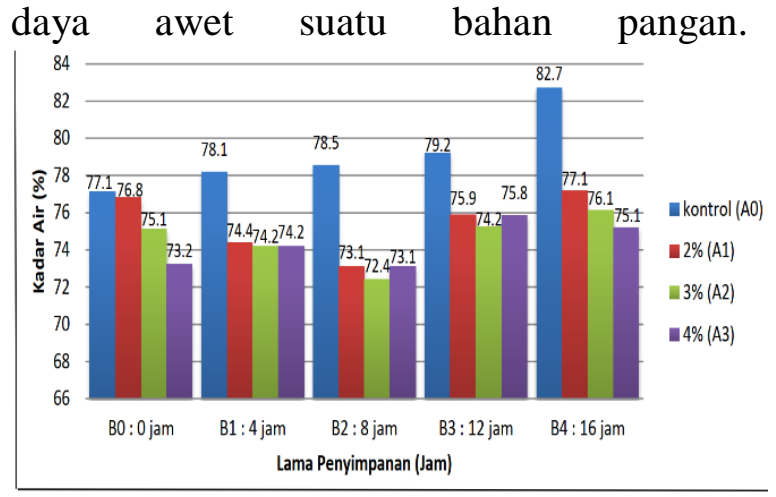

Gambar 1. Pengaruh konsentrasi ekstrak daun palliasa terhadap kadar air ikan kembung yang disimpan pada suhu ruang.

\subsection{Derajat Keasaman (pH)}

Perubahan $\mathrm{pH}$ daging ikan sangat besar peranannya karena berpengaruh terhadap proses autolisis dan penyerangan bakteri. Berdasarkan hasil analisa sidik ragam menunjukkan pengaruh nyata pada taraf $5 \%$ sehingga dilakukan uji lanjut Duncan. Hal tersebut dapat dipengaruhi oleh perlakuan penggunaan konsentrasi ekstrak daun palliasa yang berbeda. Hasil pengujian daging ikan kembung dengan perlakuan ekstrak daun palliasa, selama penyimpanan 16 jam pada suhu ruang dapat dilihat pada Gambar 6. Analisis pH dimaksudkan untuk mengetahui derajat keasamaan pada ikan kembung selama penyimpanan pada suhu ruang pada wadah styrofoam.

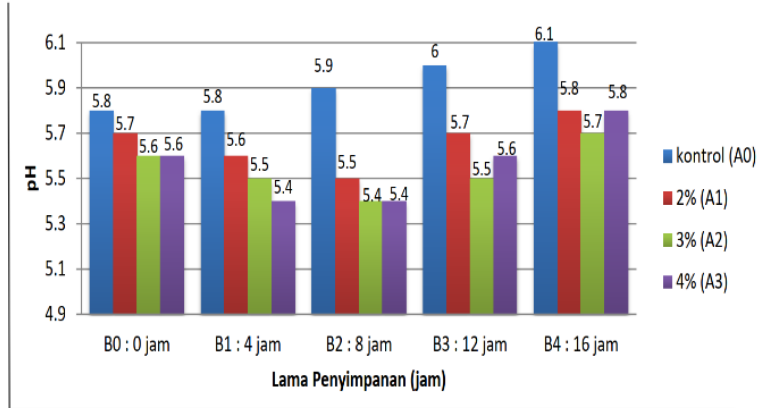

Gambar 2. Pengaruh konsentrasi ekstrak daun palliasa terhadap $\mathrm{pH}$ ikan

kembung yang disimpan pada suhu ruang

Selama penyimpanan pada suhu ruang, $\mathrm{pH}$ daging ikan kembung dengan perlakuan ekstrak daun palliasa mengalami penurunan. Penurunan nilai $\mathrm{pH}$ pada awal penyimpanan ini dapat disebabkan akibat terbentuknya asam laktat reaksi pemecahan glikogen oleh 
enzim yang terdapat pada daging. Nilai pH daging ikan kembung yang disimpan pada suhu ruang dengan perlakuan pemberian ekstrak daun palliasa berkisar antara 5,4-5,7 pada awal penyimpanan 0 jam hingga penyimpanan 8 jam, kemudian mengalami peningkatan hingga jam ke-12 dan jam ke-16 yang berkisar antara 5,5-6,1. Hal ini dapat dipengaruhi oleh lamanya penyimpanan sehingga menuju kearah basa dari proses perombakan protein pada daging ikan oleh enzim dan bakteri. Hal ini sesuai dengan Santoso et al (1999) yang menyatakan bahwa peningkatan nilai $\mathrm{pH}$ pada daging ikan selama penyimpanan menunjukkan adanya aktivitas enzim proteolitik yang terdapat pada jaringan daging ikan sehingga terbentuk senyawa amonia yang bersifat basa. $\mathrm{pH}$ yang meningkat (<7) menandakan bahwa ikan tidak segar lagi, ikan telah mengalami pembusukan dimana telah terbentuk amonia sebagai hasil akhir degradasi protein. Semakin tinggi $\mathrm{pH}$ menandakan semakin banyak amonia yang terbentuk. Oleh karena itu, $\mathrm{pH}$ dapat digunakan untuk menentukan perubahan yang terjadi pada ikan.

\subsection{Total Mikroba}

Kerusakan bahan pangan dapat disebabkan oleh beberapa faktor, salah satunya adalah kerusakan oleh mikrobiologi. Hasil pengujian total mikroba daging ikan kembung dengan perlakuan ekstrak daun palliasa selama penyimpanan pada suhu ruang dapat dilihat pada Gambar 7. Hasil menunjukkan bahwa kandungan total mikroba pada daging ikan kembung semakin meningkat seiring dengan lamanya penyimpanan.

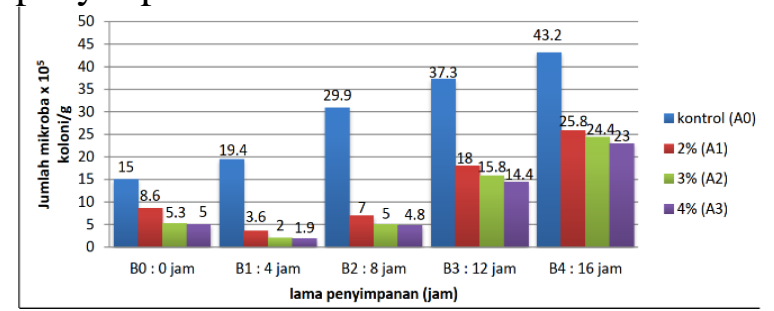

Gambar 3. Pengaruh konsentrasi ekstrak daun palliasa terhadap jumlah bakteri total (TPC) ikan kembung yang disimpan pada suhu ruang.

Gambar diatas terlihat hasil perhitungan Uji Total Mikroba bahwa jumlah bakteri pada ikan kembung yang diberikan perlakuan ekstrak daun palliasa memiliki jumlah mikroba yang lebih rendah dibandingkan dengan tanpa pemberian ekstrak (kontrol). Berdasarkan hasil analisis sidik ragam menunjukkan pengaruh nyata dari setiap perlakuan yang diberikan, sehingga dilakukan uji lanjut Duncan. Pemberian ekstrak daun palliasa mampu menghambat pertumbuhan bakteri dan memperpanjang masa simpan ikan kembung. Hasil menunjukkan bahwa perhitungan uji total mikroba untuk semua perlakuan ekstrak daun palliasa $(2 \%, 3 \%$, dan 4\%), mengalami peningkatan. Selama penyimpanan ikan kembung yang telah direndam daun palliasa selama 15 menit dan ditiriskan serta ditempatkan di styrofoam pada suhu ruang, total mikroba daging ikan kembung dengan perlakuan ekstrak daun palliasa mengalami penurunan pada jam ke 8. Penurunan total mikroba pada awal penyimpanan ini disebabkan akibat kandungan anti mikroba yang terdapat pada daun palliasa mampu menghambat pertumbuhan pada daging ikan. Demikian pula menurut Wiwi (2005), daun palliasa memiliki senyawa antimikroba yaitu fenol dan turunan-turunannya seperti alkaloid, flavonoid, terpenoid. Jenis mikroba yang dapat dihambat seperti Salmonella typhi, Staphylococcus aureus dan Streptococcus mutans. Setelah penyimpanan selama jam ke 12 hingga akhir masa penyimpanan jam ke 16 terjadi kenaikan total mikroba, hal ini dipengaruhi oleh lamanya penyimpanan. Seiring dengan lamanya penyimpanan menyebabkan jumlah bakteri meningkat, karena daging ikan merupakan media yang sangat baik untuk ditumbuhi oleh mikroba. Hal demikian dikarenakan kandungan protein $(20,10 \%)$ pada daging ikan cukup tinggi sehingga memudahkan bakteri untuk tumbuh juga dapat dipengaruhi oleh lamanya penyimpanan. Hal ini sesuai dengan Liviawaty dan Afrianto (2010), yang 
menyatakan bahwa peningkatan total mikroba selama penyimpanan menunjukkan penurunan tingkat kesegaran pada ikan.

Perhitungan uji total mikroba menunjukkan bahwa daging ikan kembung dengan adanya pemberian ekstrak daun palliasa yaitu pada perlakuan $3 \%$ dengan lama penyimpanan 8 jam telah memenuhi persyaratan standar mutu ikan segar dengan jumlah (Sedangkan sampel ikan kembung yang memiliki perhitungan yang paling tinggi adalah ikan kembung tanpa pemberian ekstrak daun palliasa (kontrol) dengan jumlah. Berdasarkan aturan SNI 012729.1-2006 BSN (2006), bahwa kandungan maksimal bakteri pada ikan untuk dapat dikatakan segar dan layak dikonsumsi yaitu CFU/g. Hasil analisis total mikroba menunjukkan bahwa perlakuan perendaman dalam larutan ekstrak daun palliasa mampu menghambat pertumbuhan bakteri ikan kembung selama 8 jam. Kandungan total bakteri pada daging ikan kembung semakin meningkat seiring dengan lamanya penyimpanan, akan tetapi jumlah bakteri pada ikan kembung yang diberikan perlakuan ekstrak daun palliasa yang disimpan $>8$ jam lebih tinggi dan melampaui standar SNI 01-2729.1-2006, hal ini diduga zat pengawet fenol pada daun palliasa konsentrasinya menurun sehingga tidak mampu menahan pertumbuhan mikroba.

\subsection{Uji Organoleptik}

Pengujian organoleptik merupakan salah satu cara yang digunakan dalam penelitian ini, guna untuk menentukan mutu kesegaran ikan kembung yang menggunakan ekstrak dari daun palliasa. Pengujian organoleptik merupakan cara pengujian yang bersifat subjektif yang menggunakan indra yang ditujukan pada mata, insang, lendir permukaan badan, daging, bau, dan tekstur pada ikan. Metode yang digunakan dalam pengujian organoleptik yaitu menggunakan score sheet berdasarkan SNI 01-2346-2006 (BSN 2006). Uji organoleptik merupakan hasil reaksi fisikologi berupa tanggapan atau kesan mutu oleh panelis. Panelis adalah sekelompok orang yang bertugas menilai sifat atau kualitas bahan berdasarkan kesan subjektif. Panelis dapat dibagi menjadi enam kelompok yaitu panelis pencicipan perorangan, panelis pencicipan terbatas, panelis terlatih, panelis agak terlatih, dan panelis konsumen. Pengujian bahan pangan dengan panelis agak terlatih sering dilakukan karena tidak memerlukan panelis yang memiliki kepekaan tinggi. Panelis agak terlatih biasanya merupakan sekelompok mahasiswa atau staf peneliti (15 sampai 25 orang) yang mengetahui sifat-sifat sensorik dari contoh yang dinilai melalui penjelasan atau latihan sebelumnya (Soekarto, 1995)

\subsection{Nilai Kenampakan Mata}

Kesegaran adalah salah satu parameter untuk menentukan baik atau tidaknya ikan tersebut. Parameter dalam menentukan kesegaran atau kualitas ikan dapat meliputi faktorfaktor seperti faktor kimiawi, fisikawi, mikrobiologi maupun organoleptik (Hadiwiyoto, 1993). Penentuan kesegaran ikan dapat dilihat dengan faktor fisikawi yang terdiri dari kenampakan luar seperti mata. Hasil penelitian terhadap nilai kenampakan mata dapat dilihat pada Gambar 4.

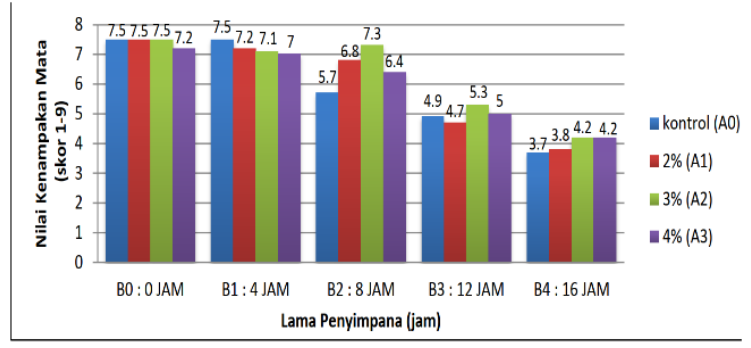

Gambar 4. Hasil Kenampakan Mata Ikan Kembung (Rastrelliger sp) yang Disimpan pada Suhu Ruang

Nilai organoleptik kenampakan mata pada ikan kembung dengan perlakuan ekstrak daun palliasa selama penyimpanan suhu ruang dapat dilihat pada Gambar 07. Nilai organoleptik kenampakan mata ikan kembung pada tiap konsentrasi ekstrak daun palliasa yang digunakan mengalami penurunan seiring dengan lama penyimpanan, yakni memiliki skor 7,5 pada awal penyimpanan kemudian menurun 
hingga skor 3-4 pada akhir penyimpanan. Dari hasil penilaian panelis terhadap kenampakan mata pada ikan kembung yang memiliki nilai tertinggi adalah ikan yang diberi perlakuan ekstrak daun palliasa $2 \%$ dan 3\% dengan nilai yang sama yaitu 7,5 pada pengamatan 0 jam. Pada pengamatan 4-8 jam untuk perlakuan 2\%, 3\% dan $4 \%$ memiliki nilai antara 6,4-7,3. Panelis dapat menilai kenampakan mata ikan masih dalam keadaan segar. Hal ini dapat dilihat dari ciriciri kenampakan ikan yang memiliki kenampakan mata yang masih cerah, bola mata rata dan kornea yang jernih. Penilaian panelis terhadap kenampakan mata ikan kembung pada penyimpanan 12- 16 jam untuk perlakuan $2 \%, 3 \%$ dan $4 \%$ memiliki nilai antara 3,8-5,3. Kenampakan mata ikan kembung pada penyimpanan 12-16 jam tidak diterima oleh panelis. Nilai tersebut telah menunjukkan ciri-ciri kenampakan mata yang mulai cekung, pupil berubah keabuabuan dan kornea mata yang tidak jernih lagi. Mata ikan kembung dengan perlakuan ekstrak daun palliasa memiliki penurunan nilai organoleptik mata yang lebih kecil dibandingkan dengan penurunan nilai organoleptik yang terjadi tanpa pemberian ekstrak (kontrol). Penurunan nilai kenampakan mata dipengaruhi oleh lamanya masa simpan. Hal ini sesuai dengan Widyasari (2006) yang menyatakan bahwa dengan semakin lama masa simpan ikan maka nilai kenampakan akan terus menurun. Hal tersebut disebabkan oleh perubahan-perubahan fisik, kimiawi dan mikrobiologi. Dapat dikatakan bahwa perubahan kenampakan mata ikan kembung dari cembung ke cekung terjadi iakibat adanya kerusakan pada kornea dan pupil ikan yang disebabkan oleh aktivitas mikroba.

\subsection{Nilai Kenampakan Insang}

Kesegaran ikan merupakan hal sangat penting dalam menentukan keseluruhan mutu daripada suatu produk perikanan. Mutu kesegaran dapat mencakup rupa atau kenampakan seperti dengan melihat kondisi ikan tersebut. Insang adalah salah satu anggota tubuh dari ikan yang mudah dikenali, apabila ikan telah mengalami kerusakan atau penurunan mutu yaitu insang berwarna coklat kehitaman, sehingga tidak termasuk dalam golongan ikan yang segar lagi. Perubahan fisik pada ikan khususnya bagian insang disebabkan oleh Hasil penelitian terhadap nilai insang dapat dilihat pada Gambar 5.

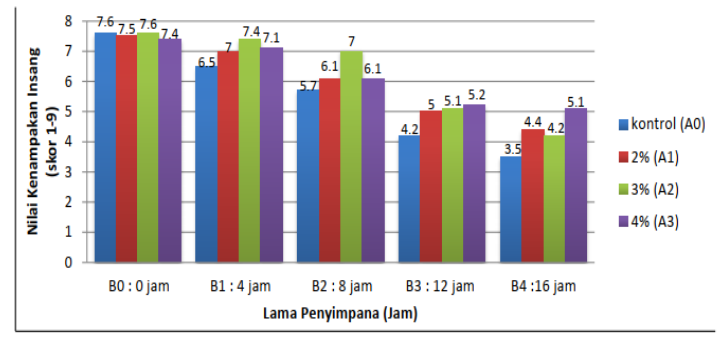

Gambar 5. Hasil Kenampakan Insang pada Ikan Kembung (Rastrelliger $s p$ ) yang Disimpan pada Suhu Ruang

Nilai organoleptik kenampakan insang ikan kembung pada tiap konsentrasi ekstrak daun palliasa yang digunakan mengalami penurunan seiring dengan lama penyimpanan, yakni memiliki skor 7,4-7,6 pada awal penyimpanan kemudian menurun hingga skor 3,5- 5,1 pada akhir penyimpanan.

Hasil penilaian panelis terhadap kenampakan insang pada ikan kembung yang memiliki nilai tertinggi adalah ikan yang diberi perlakuan ekstrak daun palliasa $2 \%$ dengan nilai 7,6 pada pengamatan 0 jam. Tingginya penilaian panelis terhadap pengamatan 0 jam karena masih memiliki ciri-ciri ikan segar yaitu kenampakan insang yang memiliki warna merah cemerlang dan belum berlendir. Pada pengamatan 4-8 jam untuk perlakuan $2 \%, 3 \%$ dan $4 \%$ memiliki kisaran nilai antara 6,1-7,4. Panelis menilai dari 4-8 jam, ikan masih dalam kondisi segar. Hal ini dapat dilihat dari ciri-ciri insang ikan yaitu warna merah agak cemerlang dan tanpa lendir. Penilaian panelis terhadap kenampakan insang ikan kembung pada penyimpanan 12-16 jam untuk perlakuan $2 \%, 3 \%$ dan $4 \%$ memiliki nilai antara 4,2-5,2. Penilaian pada pengamatan 12-16 jam tidak diterima panelis. Penurunan nilai 
organoleptik pada kenampakan insang ikan kembung dengan perlakuan ekstrak daun palliasa memiliki penurunan nilai yang relative rendah dibandingkan dengan tanpa perlakuan atau tanpa pemberian ekstrak daun palliasa (kontrol).

Berdasarkan gambar 5 menunjukkan bahwa perbandingan antara kontrol dengan perlakuan penambahan ekstrak daun palliasa cenderung mengalami penurunan. Penurunan yang cenderung stabil ini disebabkan oleh daya simpan pada ikan. Daya simpan pada ikan mempengaruhi penurunan kesegaran pada ikan. Penurunan mutu telah menunjukkan ciriciri insang ikan yang tidak segar lagi dengan insang yang sudah berwarna merah coklat (BSN, 2006). Insang pada ikan merupakan salah satu organ tubuh ikan yang mudah mengalami perubahan warna. Adanya perubahan warna yang terjadi pada insang menunjukkan bahwa ikan tersebut telah mengalami penurunan mutu. Dipertegas oleh Septiani (2008), bahwa insang ikan termasuk organ tubuh yang paling rentan terhadap kebusukan dan cepat mengalami kebusukan dibanding dengan tubuh lainnya karena akumulasi bakteri dalam jumlah tinggi pada insang. Adanya perubahan warna insang pada ikan ini disebabkan oleh peredaran darah pada bagian tubuh ikan terhenti sehingga darah teroksidasi yang menyebabkan warna insang berubah.

\subsection{Nilai Kenampakan lendir}

Hasil penelitian terhadap nilai kenampakan lendir pada ikan kembung selama penyimpanan suhu ruang dapat dilihat pada Gambar 6.

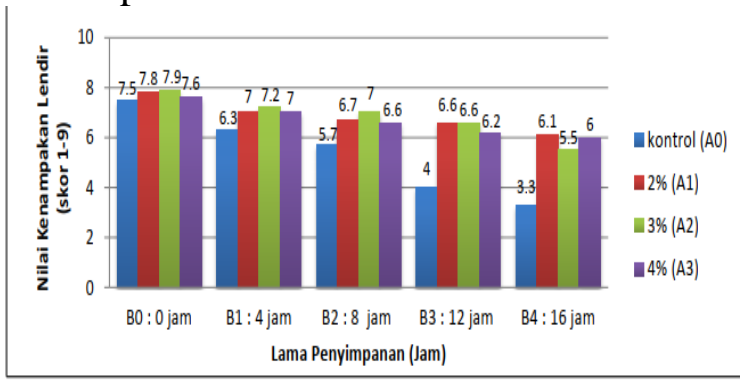

Gambar 6. Nilai Kenampakan Lendir pada

Ikan Kembung (Rastrelliger $s p$ ) yang

Disimpan pada Suhu Ruang
Nilai organoleptik kenampakan lendir ikan kembung pada tiap konsentrasi ekstrak daun palliasa yang digunakan mengalami penurunan seiring dengan lama penyimpanan, yakni memiliki skor 7,6-7,9 pada awal penyimpanan kemudian menurun hingga skor 5,5- 6,1 pada akhir penyimpanan. Dari hasil penilaian panelis terhadap kenampakan lendir pada ikan kembung yang memiliki nilai tertinggi adala ikan yang diberi perlakuan ekstrak daun palliasa $3 \%$ pada pengamatan 0 jam. tingginya penilain panelis terhadap pengamatan pada 0 jam karena masih memiliki ciri-ciri ikan segar yaitu dengan kenampakan dengan lapisan lendir yang jernih, transpaaran, mengkilat cerah. Pada pengamatan 4-8 jam untuk perlakuan $2 \%$, $3 \%$ dan 4\% memiliki nilai antara 6,6-7,2. Panelis dapat menilai kenampakan lendir pada ikan kembung pada pengamatan 4-8 jam menunjukkan bahwa ikan masih dikategorikan masih dalam keadaan yang segar. Hal ini dapat dilihat dari ciriciri lendir pada permukaan tubuh ikan yaitu lapisan lendir yang mulai agak keruh, warna. agak putih dan kurang transparan serta adanya perlakuan perendaman ekstrak daun palliasa yang dilakukan sehingga memberikan efek dan nilai organoleptik yang lebih baik. Penilaian panelis terhadap kenampakan lendir pada permukaan tubuh ikan kembung pada penyimpanan 12-16 jam untuk perlakuan $2 \%, 3 \%$ dan $4 \%$ memiliki nilai antara 5,5-6,6.

Panelis menilai bahwa pengamatan 12-16 jam masih diterima panelis walaupun nilai yang dihasilkan tetap berkurang dari pengamatan 4-8 jam. Gambar 10 menunjukkan Penurunan mutu ikan dipengaruhi oleh adanya proses pembusukan ikan yang terjadi. Hal ini diperkuat oleh Murniati dan Sunarman (2000), yang menyatakan bahwa proses pembusukan ikan terjadi tahap Hiperaemia yaitu lendir ikan terlepas dari kelenjarkelenjarnya didalam kulit, membentuk lapisan bening yang tebal disekeliling tubuh ikan. Pelepasan lendir dari kelenjar lendir ini 
merupakan reaksi alami ikan yang sedang sekarat terhadap keadaan yang tidak menyenangkan. Lendir yang terbentuk pada permukaan kulit ikan, hilangnya warna alami atau biasa disebut dengan diskolorisasi merupakan tanda-tanda adanya kemunduran mutu pada ikan yang disebabkan oleh adanya aktivitas mikroorganisme.

\subsection{Nilai Aroma}

Nilai organoleptik aroma daging ikan kembung dengan perlakuan ekstrak daun palliasa selamam penyimpanan suhu ruang dapat dilihat pada Gambar 7

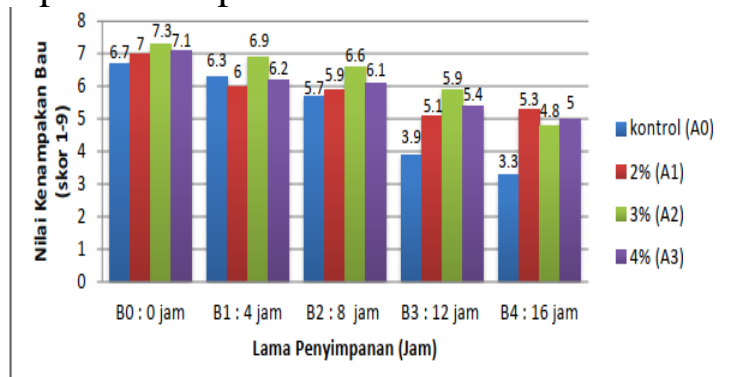

Gambar 7. Nilai KenampakanBau pada

Ikan Kembung (Rastrelliger sp) yang

Disimpan pada Suhu Ruang

Nilai organoleptik bau daging ikan kembung pada tiap konsentrasi ekstrak daun palliasa yang digunakan mengalami penurunan seiring masa penyimpanan. Nilai organoleptik kenampakan bau ikan kembung pada tiap konsentrasi ekstrak daun palliasa yang digunakan mengalami penurunan seiring dengan lama penyimpanan, yakni memiliki skor 7-7,3 pada awal penyimpanan kemudian menurun hingga skor 4,8-5,3 pada akhir penyimpanan. Dari hasil penilaian panelis terhadap kenampakan bau pada ikan kembung yang memiliki nilai tertinggi adalah ikan yang diberi perlakuan ekstrak daun palliasa $2 \%$ dengan nilai 7,3 pada pengamatan 0 jam. Tingginya penilaian panelis pada pengamatan 0 jam karena ikan masih memiliki ciri-ciri ikan segar yaitu bau sangat segar, spesifik jenis ikan. Pada pengamatan 4-8 jam untuk perlakuan 2\%, $3 \%$ dan $4 \%$ memiliki nilai antara 5,9- 6,9. Pada pengamatan 12-16 jam, penilaian panelis terhadap bau semakin menurun. Hal ini dapat dikatakan bahwa penilaian bau dari mulai pengamatan 12-16 jam tidak diterima oleh panelis. Hal ini dapat dipengaruhi oleh adanya lama penyimpanan. Seiring dengan lamanya penyimpanan menyebabkan nilai organoleptik oleh bau panelis semakin menurun. Selain faktor penyimpanan, meningkatnya bau atau aroma pada ikan dapat dipengaruhi pula kandungan lemak dan minyak yang terdapat pada ikan sehingga ikan tersebut mudah mengalami proses pembusukan. Hal ini sesuai dengan Amin (2008), yang menyatakan bahwa kandungan lemak dan minyak pada bahan pangan mempengaruhi ketengikan rasa dan aroma. Ikan dengan kandungan asam lemak tinggi akan lebih cepat mengalami pembusukan. Peningkatan bau tersebut dapat dipengaruhi faktor temperatur penyimpanan. Daging ikan kembung dengan perlakuan ekstrak daun palliasa memiliki bau khas daun palliasa yang menutupi bau dari daging ikan sendiri, sehingga tidak terlalu tercium bau ammonia yang menyengat seperti pada daging ikan kembung tanpa perlakuan ekstrak daun palliasa (kontrol).

\subsection{Nilai Tekstur}

Nilai organoleptik tekstur daging ikan kembung dengan perlakuan daun palliasa selama penyimpanan pada suhu ruang dapat dilihat pada Gambar 8 .

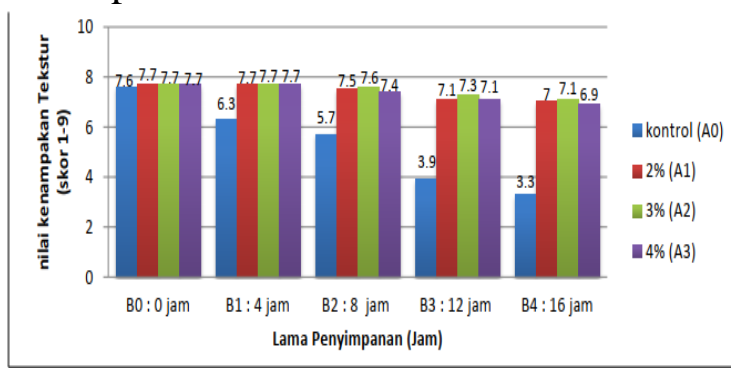

Gambar 8. Hasil Kenampakan Tekstur pada Ikan Kembung (Rastrelliger sp) yang Disimpan pada Suhu Ruang

Nilai organoleptik tesktur daging ikan kembung yang diberi perlakuan ekstrak daun palliasa mengalami penurunan seiring masa penyimpanan, namun penurunan 
relatif kecil. Pada penyimpanan awal memiliki skor 7,7 kemudian menurun hingga skor 6,9-7,5. Penurunan nilai organoleptik tekstur daging ikan kembung pada masa penyimpanan jam ke-8 masih berkisar pada kondisi batas penerimaan oleh panelis yaitu 7,4-7,6 untuk daging ikan kembung dengan perlakuan ekstrak daun palliasa dengan konsentrasi $2 \%$, $3 \%$ dan $4 \%$. Namun untuk kontrol atau tanpa perlakuan ekstrak daun palliasa sudah mengalami penolakan oleh panelis (skor < 7,0). Daging ikan kembung dengan perlakuan ekstrak daun palliasa memiliki penurunan nilai organoleptik tekstur yang lebih kecil dibandingkan dengan penurunan nilai organoleptik yang terjadi pada daging ikan kembung tanpa pemberian ekstrak daun palliasa (kontrol). Lama penyimpanan jam ke-16 didapatkan daging ikan kembung tanpa perlakuan ekstrak daun palliasa memiliki tekstur yang sangat lunak, bekas jari tidak hilang bila ditekan atau dapat dikatakan daging ikan kembung tidak elastis dan daging sangat mudah lepas terurai, hal tersebut disebabkan karena adanya proses degradasi protein oleh bakteri pembusuk (Widiastuti, 2008).

Daging ikan kembung dengan perlakuan ekstrak daun palliasa, memiliki tekstur daging yang sedikit lebih kompak dibandingkan dengan daging tanpa perlakuan ekstrak, hal ini menunjukkan bahwa ekstrak daun palliasa memiliki pengaruh menghambat aktivitas bakteri, sehingga proses degradasi protein terhambat dan kerusakan tekstur daging dapat lebih dihambat dalam masa penyimpanan. Perubahan tekstur daging ikan dipengaruhi oleh aktivitas enzim yang semakin meningkat pada proses autolysis sehingga menyebabkan tekstur daging ikan menjadi lembek. Bakteri sudah mulai merusak ikan dengan mengurangi protein daging.

\section{KESIMPULAN}

Berdasarkan hasil penelitian perlakuan konsentrasi daun palliasa yaitu $2 \%, 3 \%$, dan $4 \%$ terhadap kesegaran ikan kembung selama penyimpanan 16 jam pada suhu ruang, dapat disimpulkan bahwa keefektifan daun palliasa (Kleinhovia hospita L), dalam mempertahankan kesegaran ikan kembung berdasarkan pengujian sifat kimia, mikrobiologi dan organoleptik adalah : 1 . Tingkat kesegaran ikan kembung selama penyimpanan 8 jam pada suhu ruang dengan perlakuan pemberian ekstrak daun palliasa $3 \%$ dapat mempertahankan kesegaran berdasarkan analisis kimia yaitu kadar air yang terendah $72,4 \%$ dan $\mathrm{pH}$ 5,4 .

Pemberian ekstrak daun palliasa 3\% mampu menekan pertumbuhan mikroba selama 8 jam penyimpanan ikan kembung di wadah sterefoam di bawah standar SNI $5 \times 10^{5}$ koloni/gram.

Uji organoleptik kesegaran ikan kembung selama penyimpanan suhu ruang dengan perlakuan pemberian ekstrak daun palliasa $3 \%$ berdasarkan kenampakan mata diperoleh nilai rata-rata 6.28, kenampakan insang 6.28 , lendir permukaan tubuh 6.78, aroma 6.3 dan tekstur 7.48.

\section{DAFTAR PUSTAKA}

Buckle, (1987) Ilmu Pangan. Penerjemah Hari Purnomo, Adiyono, (Ui-press) Jakarta.

Santoso J, Nurjanah, Sukarno, Sinaga SR. (1999). Kemunduran mutu ikan nila merah (Oreochromis sp.) selama penyimpanan pada suhu chilling. Buletin Teknologi Hasil Perikanan 4:1-4

Wiwi, D., Hasriani. A (2005) Dua Senyawa Triterpenoid dari Tumbuhan Palliasa (Kleinhovia Hospita L.) Famili Sterculiaceae. J. Sains MIPA, 16 (2) : 9498

Liviawaty E, Afrianto E. (2010). Penanganan Ikan Segar, Proses Penurunan dan Cara Mempertahankan Kesegaran Ikan. Bandung: Widya Padjajaran.

Balai Pengkajian Teknologi Pertanian [BPTP]. (2009). Metodologi Perikanan. www.geocities.com. [5 Maret 2009] 
NI 01-2729.2. (2006): Ikan Segar-Bagian 2: Persyaratan Bahan Baku. Badan Standarisasi Nasional, Jakarta.10 p

Soekarto, S.T. (1995). Penilaian Organoleptik untuk Industri Pangan dan Hasil Pertanian. Bharata Karya Aksara, Jakarta

Hadiwiyoto. (1993). Karakteristik Daging Ikan Segar berdasarkan hubungan $\mathrm{pH}$ dengan keadaan bakteri. Indones. J. App. Chem 18 (June): 63-71.

Widiastuti. (2008). Pendinginan pembekuan dan pengawetan ikan. Yogyakarta: Kanisius

Septiani. (2008). ciri-ciri ikan yang telah mengalami proses pembusukan akibat proses penyimpanan. Universitas Diponegoro. Semarang.

Murniati, A.S. dan Sunarman. (2000). Pendinginan, Pembekuan, Pengawetan Ikan. Penerbit Kanisius, Yogyakarta. hal. 5-21

Amin, I. (2008). Aplikasi Ekstrak Daun Sirih dalam Menghambat Oksidasi Lemak Jambal Patin. Tesis. Sekolah Pascasarjana Institut Pertanian Bogor, Bogor. hal. 1-2

Widiastuti. (2008). Pendinginan pembekuan dan pengawetan ikan. Yogyakarta: Kanisius 